\title{
Practitioner's Corner
}

Comparative Economic Studies (2006) 48, 213. doi:10.1057/palgrave.ces.8100165

\section{Introduction}

This is the second in a series of papers in a new section of the journal which we call 'Practitioner's Corner.' The purpose of this series is to invite prominent policymakers to relate their experiences in the hope that this will be intellectually stimulating and help academics to set their future research agendas.

Peter Nicholl was appointed Governor of the Central Bank of Bosnia and Herzegovina $(\mathrm{CBBH})$ by the Managing Director of the IMF with the approval of the Presidency of Bosnia and Herzegovina in October 1997. The Law of the $\mathrm{CBBH}$ stipulated that after six years the Governor of the $\mathrm{CBBH}$ would be a Bosnian citizen. After six years Nicholl was given citizenship so he could continue as Governor for another year. He remained Governor until 31 December 2004 and then served another year as a board member. In 2003, the British financial magazine 'Finance Central Europe', named the $\mathrm{CBBH}$ as the best central bank and Nicholl Governor of the Year in the Southeast Europe region.

In this essay, Nichol compares his experience as Governor of the $\mathrm{CBBH}$ to his experience in New Zealand where he worked for twenty-two years and was deputy governor for last five years. He argues that while there are differences between the two environments, there are also many similarities and that clear laws and good operating procedures are needed for successful administration of public institutions in either place. 